\title{
The impact of two education methods on knowledge of schistosomiasis transmission and prevention among schoolchildren in a rural community in northern Minas Gerais, Brazil
}

\author{
Maria Flávia Gazzinelli, Dener Carlos dos Reis, Helmut Kloos*, \\ Gustavo Velásquez-Melendez, Izabela Rocha Dutra, Andréa Gazzinelli/ ${ }^{+}$
}

Escola de Enfermagem, Universidade Federal de Minas Gerais, Av. Alfredo Balena 190, 30130-100 Belo Horizonte, MG, Brasil

*Department of Epidemiology and Biostatistics, University of California Medical Center, San Francisco, CA, US

The objective of this study was to analyse the effect of using two health education approaches on knowledge of transmission and prevention of schistosomiasis of school children living in a rural endemic area in the state of Minas Gerais, Brazil. The 87 children participating in the study were divided into three groups based on gender, age and presence or absence of Schistosoma mansoni infection. In the first group the social representation model and illness experience was used. In the second group, we used the cognitive model based on the transmission of information. The third group, the control group, did not receive any information related to schistosomiasis. Ten meetings were held with all three groups that received a pre-test prior to the beginning of the educational intervention and a post-test after the completion of the program. The results showed that knowledge levels in Group 1 increased significantly during the program in regard to transmission $(p=0.038)$ and prevention $(p=0.001)$ of schistosomiasis. Groups 2 and 3 did not show significant increase in knowledge between the two tests. These results indicate that health education models need to consider social representation and illness experience besides scientific knowledge in order to increase knowledge of schistosomiasis transmission and prevention.

Key words: schistosomiasis - health education - evaluation models - Brazil

Schistosomiasis is a serious public health problem with more than 200 million individuals infected in the world and approximately 2.5 milion in Brazil and is also one of the most difficult parasitic diseases to control (WHO 2001). Reasons for the persistence of schistosomiasis in spite of prolonged and intensive control and prevention efforts include migration patterns and residence, the wide distribution of the intermediate hosts, the dependence of many poor populations in both rural and urban areas on schistosome-infested water sources for their domestic, occupational, and recreational needs, lack of sanitation and potable water, and scarcity of and deficiencies in preventive and curative health services (Coura-Filho 1998, Ximenes et al. 2000, WHO 2001, Funasa 2002). Chemotherapy is still the main means of managing morbidity from schistosomiasis. However, the prevention of reinfection, the infection of others, and the reduction in the incidence of infection require that attention be given to socioeconomic, cognitive, behavioral, and other factors (Kloos 1995, Kloos et al. 1998, Barbosa 1998, Uchôa et al. 2000, Asaolu \& Ofoezie 2003). Health education in conjunction with environmental sanitation and safe water supplies has been described as a potentially effective strategy in schis-

Financial support: CNPq, Fapemig

${ }^{+}$Corresponding author: andreag@enf.ufmg.br

Received 25 May 2006

Accepted 26 June 2006 tosomiasis control (Barbosa 1995, Coura 1995, Dias et al. 1995, Kloos 1995, Schall 1998, Gazzinelli et al. 1998, 2002, Funasa 2002).

Developing health education programs requires that their design, administration, and outcomes be adapted to different socioeconomic and cultural settings (Kloos 1995, Parker et al. 2004). Since the institutionalization of health education in the national disease control programs in Brazil in the early 1920s (Levy et al. 2003) theoretical and methodological improvements have been made in the development and operationalization of health education programs. One evidence of this improvement is the change in some health education programs from an intervention developed and controlled by the government in a top-down fashion to a more community-based, participative approach that is based on the population's commitment to the health process (Vasconcelos 1998).

During the last few decades, several studies showed that the individual's assimilation of scientific knowledge does not necessarily result in behavioral changes facilitating disease prevention and control. It is becoming increasingly clear that behavior as related to perceptions, values, social representations, power relationships, beliefs, and feelings cannot be changed simply with the acquisition of knowledge imparted by health education (Gastaldo 1997, Glanz et al. 2002, Cross 2005, Gazzinelli et al. 2005). According to Peregrino (2000), Barata and Briceño-León (2000), health education programs limited to providing information to the population on specific health problems without considering the socioeconomic and cultural context of communities are usually unsuccessful. 
Therefore, it is necessary to consider individuals and communities in the totality of their environment when developing educational programs for the control of endemic diseases. The success of programs in reducing highrisk behavior and promoting health-enhancing behavior depends to a considerable degree on whether life cycle and other biomedical concepts and information are presented in the intelectual, emotional, social, economic, and cultural context of target populations (Barata \& BriceleñoLeón 2000, Reis 2003, Parker et al. 2004, Gazzinelli et al. 2005). In order to achieve these objectives, the development of health programs should be based on the social representation and experience of infected individuals (Cardoso \& Gomes 2000, Reis 2003, Gazzinelli et al. 2005). It is known that representations of individuals are based on their experiences and practices which, in turn, change the representations (Moscovici 2000, Cardoso \& Gomes 2000).

In this study, we compare the social representation and experience of the individual approach with a cognition approach in regard to their appropriated and effectiveness in changing knowledge and behavior surrounding schistosomiasis transmission and control. The social representation approach has been associated with increased individuals' conciousness about their autonomy in decision making and co-responsible, ethical, and positive behaviors that effectively contribute to the reduction of endemic diseases prevalences in several endemic areas in Brazil (Mhor \& Schall 1992, Schall 1998, Dias 2000, Uchôa et al. 2000, Reis 2003).

Whereas some studies have shown an impact of health education on the acquisition of knowledge and risk behavior (Reis 2003, Freudenberg 2005, Dofman et al. 2005) others failed to demonstrate any beneficial effects (Valla $\&$ Oliveira 2001). Reasons for unsuccessful health education programs include the failure to consider appropriate theoretical constructs that were developed over the years and also the scarcity of experimental studies in this area. These deficiencies render the evaluation of the impact of health education programs on changes in behaviors and practices related to schistosomiasis more difficult (Lima e Costa et al. 2002). Most studies focus on the effect of different teaching/learning approaches on knowledge change but fail to explain behavioral change (Sow et al. 2002, Lansdown et al. 2002, Poggensee et al. 2005, GuangHan et al. 2005).

This study is part of an ongoing multidisciplinary project that was developed in the rural community of Caju in the impoverished Jequitinhonha Valley of northern Minas Gerais in 2003 to identify risk factors in Schistosoma mansoni infection and reinfection, the relationship between infection and nutrition and with anthropometric parameters. The objective of this multidisciplinary project is to evaluate the impact of a health education program using two teaching approaches on knowledge, perceptions and behavior about $S$. mansoni transmission among schoolchildren. The first approach is based on social representation and experience with illness and the second approach on cognition.

\section{MATERIALS AND METHODS}

Study area and population - The study was carried out in Caju, a rural community in Jequitinhonha municipality, where schistosomiasis mansoni is hyperendemic and the government treatment program has not yet been implemented. The prevalence of schistosomiasis in 2003 was 63\% (Centro de Pesquisas René-Rachou/Fiocruz, unpublished data). According to our census, 627 individuals, $304(48.5 \%)$ females and $323(51.5 \%)$ males lived in the study area in 130 households in 2003 . The population lived on dispersed homesteads in the area's four hamlets and a nucleated central village. The nearest medical services are $60 \mathrm{~km}$ distant over a rough dirt road. The four hamlets and the central village of Caju depend on the streams, canals, wells, springs and piped dams for their domestic, occupational and recreational water needs. The prevailing mixed agriculture is of the subsistence type and characterized by cultivation of manioc, corn and beans, and cattle raising.

The central village has a single public elementary school for children who live in Caju and surrounding areas. All school-age children living in Caju and in the four hamlets within the project area and who provided stool specimens for parasitological exams and received chemotherapy were included in the study.

Study groups and the health education intervention - An interventional study was conducted on 128 students randomly divided into three groups matched by age and sex. Students unwilling to participate were excluded from the study $(n=2)$. Children who moved after we started the intervention $(\mathrm{n}=2)$ or were not present in either the preor post-test or missed at least one of the classes $(n=37)$ were excluded from the study. The main reason for missing classes or the pre- and post-tests were the long distance and difficulty of transportation from their homes to the school. For the final sample we included only the 87 students who participated in all 10 educational group meetings, and had taken both pre- and post-tests administered by questionnaire. In the first group of school children $(n=26)$ the approach used was based on social representation and the experience with schistosomiasis; in the second group $(\mathrm{n}=28)$ the cognitive approach was used; and in the third ( $\mathrm{n}=33)$, or control group, we focused on subjects not related to schistosomiasis, such as personal hygiene. The intervention process was administered by the first author and two undergraduate students trained prior to the process using standardized concepts and methods.

The education program was structured and implemented as follows: Group 1- The social representation approach (Dewey 1971, Moscovici 2001) based on the experience of the children with schistosomiasis considered the following topics: (a) the previous knowledge of all school children about schistosomiasis identifying possible areas for changing; (b) the analysis of practices, attitudes, and values related to the risk of infection; and (c) student perceptions and beliefs related to the place where they live, environment and health services. We examined the relationship and interaction between their per- 
ceptions of schistosomiasis transmission/prevention and scientific knowledge. Here is an example of how the children's previous idea of transmission through polluted water only was used in a lecture. We demonstrated and discussed in class the idea of dirty water and its relationship with transmission: (1) children identified all water sources used by them stating if they considered that source a potential risk for transmission; (2) we discussed the water as means for health and illness through photographs, magazines, and newspapers; (3) students identified in a microscope the cercarie in a container with apparently clean water; (4) we discussed through theater ways the community could get potable water; and (5) we showed books, poetry, and musics about water. We followed the same technique with all other content discussed in class based on the student's previous idea about schistosomiasis such as "not wearing shoes, not washing hands after eating". We tried to make students critically think about those conceptions and slowly change to the correct knowledge about transmission of schistosomiasis. Group 2 - We used the cognitive approach (Abrantes 1994) that focuses basically on information on transmission and prevention of schistosomiasis using pre-existing education materials developed by the National Health Foundation (Funasa) and the Ministry of Health. In this approach we included questions related to the information in the educational material, what students understand about the information related to transmission and the risk of getting infected. Students were also asked to make a summary of what they learned in class. Group 3 - The control group received information related to health but not specifically to schistosomiasis. At the end of the education process, after evaluation of the intervention, this group received information about schistosomiasis like the other two groups. In this group students discussed personal hygiene, drug problems, smoking and healthy foods, and vitamins though paintings and drawings followed by group discussion.

All activities developed by the researchers in the classes as well as the materials used were based on national and international literature on health education and schistosomiasis. Intervals between classes were 30 days. Teachers stayed in class during the intervention but did not participate in any activity because they did not have the skill to use the approaches we used and we needed to guarantee that all groups received equal interventions.

The health education intervention was performed over a one year period in a total of 10 group meetings with approximately $1 \mathrm{~h}$ duration per meeting for each of the three groups. The students were grouped in three different classrooms in the morning and afternoon shifts.

This study was reviewed and approved by the Ethical Committee of the Universidade Federal de Minas Gerais. Informed consent for participation was obtained from the parents of the schoolchildren.

Questionnaires - The individual pre- and post-tests were administered through two questionnaires in the classroom setting by the researcher immediately before and after the education intervention. Open-ended questions were asked on modes of transmission and prevention of schistosomiasis. Respondents were not prompted with possible answers and multiple answers were allowed. For children 6 years old and a few aged 7 who could not write, the questions were read and their verbal responses written down by the first author.

Analysis - Answers were classified as correct or incorrect. We considered answers related to transmission to be correct if they included information on contact with fecally and sewage contaminated water, the use of nontreated water, and inadequate human excreta disposal. The correct answers for prevention mentioned adequate excreta disposal, not having contact with stream water, dams, and rivers, and drinking treated water. We considered answers to be incorrect when no answer was given, when the answer had nothing to do etiologically with schistosomiasis and when multiple responses were made, including both correct and incorrect statements.

The software package Epi Info.6.04 (Dean et al. 1994) was used for analysis. Absolute and relative frequency distributions were calculated and a chi-square test was used to compare proportions of answers before and after the health education process at a significance level of $\mathrm{p}<0.05$.

\section{RESULTS}

The final sample consisted of 87 children from 6 to 18 years old. In this group, the prevalence for schistosomiasis was $77 \%$ with a mean egg count of 325 epg (IC95\% = 197.05-452.40). The mean age of the students was 10.4 years with $37(42.5 \%)$ males and $50(57.5 \%)$ females. In Group 1 the mean age was 10.2 with 7 males and 19 females; in Group 2 the mean age was 10.1 and included 12 males and 16 females; in Group 3 the mean age was 10.7, 18 males and 15 females.

Prevention of schistosomiasis - The only group that showed a significant increase in knowledge related to prevention when comparing both pre- and post-tests results was Group 1 (19.2 to 69.2\%; p = 0.001), which had received intervention based on social representation and experience with schistosomiasis. Knowledge levels increased only moderately in Group 2 (21.4 to $32.1 \%$ ) and even declined in Group 3 (Table I) (both of them $p>0.05$ ). All three groups had low levels of knowledge related to prevention of schistosomiasis before the intervention. The percentage of incorrect questions in the pre-test was $80.8,78.6$ and $63.6 \%$ in groups 1,2 and 3 , respectively.

Results showed in the pre-test of all three groups that knowledge on prevention of disease was mainly related to the idea of avoiding contact with visibly polluted or dirty water. After the intervention, the most common answer was "to avoid contact with water containing snails". It is relevant to note here that all answers in all three groups in both pre- and post-test mentioned mainly water contact except for a few like "not defecating in streams", "not playing in dirt" and "go to the doctor".

Most incorrect answers in all three groups were related to the prevention of any helminthoses, not only schistosomiasis, such as "do not wash hands before eating", "not wearing shoes", "not eating fruits and vegetables without first washing them". The correct answers 


\section{TABLE I}

Knowledge about prevention and transmission of schistosomiasis before and after each educational approach in Caju, Jequitinhonha Valley, Minas Gerais

\begin{tabular}{|c|c|c|c|c|c|c|c|c|c|}
\hline $\begin{array}{l}\text { Reported } \\
\text { knowledge }\end{array}$ & $\begin{array}{c}(\mathrm{n}=26)^{a} \\
\text { Before } \\
(\%)\end{array}$ & 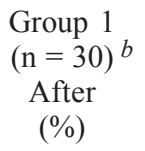 & $\mathrm{p}$ & $\begin{array}{c}(\mathrm{n}=28)^{a} \\
\text { Before } \\
(\%)\end{array}$ & $\begin{array}{c}\text { Group 2 } \\
(\mathrm{n}=23)^{b} \\
\text { After } \\
(\%)\end{array}$ & $\mathrm{p}$ & $\begin{array}{c}(\mathrm{n}=33)^{a} \\
\text { Before } \\
(\%)\end{array}$ & $\begin{array}{c}\text { Group 3 } \\
(\mathrm{n}=29)^{b} \\
\text { After } \\
(\%)\end{array}$ & $\mathrm{p}$ \\
\hline \multicolumn{10}{|l|}{ Prevention } \\
\hline $\begin{array}{l}\text { Correct } \\
\text { Incorrect }\end{array}$ & $\begin{array}{l}19.2 \\
80.8\end{array}$ & $\begin{array}{l}69.2 \\
20.8\end{array}$ & 0.001 & $\begin{array}{l}21.4 \\
78.6\end{array}$ & $\begin{array}{l}32.1 \\
70.1\end{array}$ & 0.55 & $\begin{array}{l}36.4 \\
63.6\end{array}$ & $\begin{array}{l}33.3 \\
66.7\end{array}$ & 1.0 \\
\hline \multicolumn{10}{|l|}{ Transmission } \\
\hline $\begin{array}{l}\text { Correct } \\
\text { Incorrect }\end{array}$ & $\begin{array}{l}43.3 \\
56.7\end{array}$ & $\begin{array}{l}70.0 \\
30.0\end{array}$ & 0.038 & $\begin{array}{l}56.5 \\
43.5\end{array}$ & $\begin{array}{l}52.2 \\
47.8\end{array}$ & 1.00 & $\begin{array}{l}58.6 \\
41.4\end{array}$ & $\begin{array}{l}34.5 \\
65.4\end{array}$ & 0.11 \\
\hline
\end{tabular}

$a$ : number of students answering the pre-test questions about prevention; $b$ : number of students answering the post-test questions about transmission.

TABLE II

Responses to questions on prevention of schistosomiasis in the three study groups before and after the intervention

\begin{tabular}{|c|c|c|c|c|c|}
\hline Groups & Answers & $\begin{array}{l}\text { Pre-test } \\
\text { Type of answer }\end{array}$ & $\mathrm{N}^{a}$ & $\begin{array}{l}\text { Post-test } \\
\text { Type of answere }\end{array}$ & $\mathrm{N}^{a}$ \\
\hline \multirow[t]{2}{*}{ G1 } & Correct & $\begin{array}{l}\text { Not defecating in the stream } \\
\text { Bathing in treated water } \\
\text { Drinking filtered water } \\
\text { Others }\end{array}$ & $\begin{array}{l}6 \\
3 \\
2 \\
2\end{array}$ & $\begin{array}{l}\text { Not bathing in streams containing snails } \\
\text { Not drinking water without first filtering } \\
\text { Go to the doctor } \\
\text { Bathing in a shower } \\
\text { Others }\end{array}$ & $\begin{array}{r}18 \\
9 \\
3 \\
2 \\
2\end{array}$ \\
\hline & Incorrect & $\begin{array}{l}\text { Avoiding bathing in polluted water } \\
\text { Not washing hands and not bathing } \\
\text { Not wearing shoes } \\
\text { Not drinking dirty water } \\
\text { Not crossing or working in dirty water } \\
\text { Not eating candy } \\
\text { Others } \\
\text { Total }\end{array}$ & $\begin{array}{r}25 \\
15 \\
11 \\
11 \\
11 \\
7 \\
7 \\
100\end{array}$ & $\begin{array}{l}\text { Not playing in dirty water } \\
\text { Not wearing shoes } \\
\text { Washing food before eating } \\
\text { Not playing in the dirt } \\
\text { Others }\end{array}$ & $\begin{array}{r}13 \\
10 \\
9 \\
8 \\
3\end{array}$ \\
\hline \multirow[t]{2}{*}{ G2 } & Correct & $\begin{array}{l}\text { Not drinking unfiltered water } \\
\text { Not bathing in streams with snails } \\
\text { Going to the doctor } \\
\text { Others }\end{array}$ & $\begin{array}{l}6 \\
5 \\
4 \\
2\end{array}$ & $\begin{array}{l}\text { Not bathing in streams with snails } \\
\text { Going to the doctor } \\
\text { Not drinking unfiltered water } \\
\text { Others }\end{array}$ & $\begin{array}{r}12 \\
5 \\
4 \\
4\end{array}$ \\
\hline & Incorrect & $\begin{array}{l}\text { Not playing in mud and dirty water } \\
\text { Not washing hands before eating } \\
\text { Washing uncooked food } \\
\text { Not wearing shoes } \\
\text { Others } \\
\text { Total }\end{array}$ & $\begin{array}{r}33 \\
31 \\
20 \\
12 \\
18 \\
131\end{array}$ & $\begin{array}{l}\text { Not playing in dirty water } \\
\text { Washing uncooked food } \\
\text { Not playing in the dirt } \\
\text { Others } \\
\text { Total }\end{array}$ & $\begin{array}{r}15 \\
10 \\
7 \\
4 \\
61\end{array}$ \\
\hline \multirow[t]{3}{*}{ G3 } & Correct & $\begin{array}{l}\text { Drinking clean water } \\
\text { Bathing in shower } \\
\text { Defecating in latrine } \\
\text { Others }\end{array}$ & $\begin{array}{r}19 \\
17 \\
6 \\
6\end{array}$ & $\begin{array}{l}\text { Not bathing in stream with snails } \\
\text { Going to the doctor } \\
\text { Others }\end{array}$ & $\begin{array}{r}27 \\
8 \\
4\end{array}$ \\
\hline & Incorrect & $\begin{array}{l}\text { Not bathing in dirty water } \\
\text { Not washing hands before eating } \\
\text { Not crossing dirty stream } \\
\text { Not wearing shoes } \\
\text { Others }\end{array}$ & $\begin{array}{r}18 \\
13 \\
6 \\
5 \\
5\end{array}$ & $\begin{array}{l}\text { Not playing in the dirt } \\
\text { Washing food before eating } \\
\text { Not wearing shoes } \\
\text { Taking medication } \\
\text { Doing what mother says } \\
\text { Staying home } \\
\text { Others }\end{array}$ & $\begin{array}{r}12 \\
7 \\
4 \\
4 \\
3 \\
2 \\
2\end{array}$ \\
\hline & & Total & 95 & Total & 73 \\
\hline
\end{tabular}

a: multiple answers included. 
in all three groups were associated to water and snail such as "not swimming in water with snails". In Group 1 the results showed that after the intervention the correct answers were related to "not having contact with contaminated water". However, post-test answers in groups 2 and 3 showed that most students retained incorrect information about prevention of schistosomiasis (Table II). We observed an emphasis on "snail" (such as "not bathing in stream with snail") in the correct answers about prevention in all three groups after the intervention (Table II).

Students from all three groups only weakly associated prevention with adequate disposal of excretas and the use of latrines. Such answers were given only by Group 1 students before the intervention, usually in phrases such as "not defecating in the stream" and in Group 3 "use latrine to defecate" and were not mentioned in any group after the intervention (Table II).
Schistosomiasis transmission - Children in all three groups showed a higher level of prevention knowledge after the educational intervention. However, the increase was statistically significant only in Group $1(p=0.038)$. Knowledge levels increased only slightly in Group 2 and declined in Group 3 (Table I).

The most frequent incorrect responses to the question on S. mansoni transmission, confined to Group 3 and centered around "walking without shoes". In groups 1 and 2, the most frequent correct answers in the pre- and post-tests focused on "swimming and bathing in water with snails". After the intervention most answers in those two groups, especially in Group 1, in the post-test became "bathing in contaminated water". On the other hand, many students changed the incorrect idea that schistosomiasis is transmitted when "swimming in water with excretas" and "rain water" in the pre-test to "eating fruits without cleaning" in the post-test.

TABLE III

Responses to questions on transmission of schistosomiasis in the three study groups before and after the intervention

\begin{tabular}{|c|c|c|c|c|c|}
\hline Groups & Answers & $\begin{array}{l}\text { Pre-test } \\
\text { Type of answer }\end{array}$ & $\mathrm{N}^{a}$ & $\begin{array}{l}\text { Post-test } \\
\text { Type of answere }\end{array}$ & $\mathrm{N}^{a}$ \\
\hline \multirow[t]{2}{*}{ G1 } & Correct & $\begin{array}{l}\text { Swimming in water with snails } \\
\text { Swimming in water with feces } \\
\text { Swimming in streams } \\
\text { Drinking contaminated water } \\
\text { Others }\end{array}$ & $\begin{array}{r}12 \\
8 \\
5 \\
3 \\
3\end{array}$ & $\begin{array}{l}\text { Bathing in contaminated water } \\
\text { Snail } \\
\text { Swimming } \\
\text { Others }\end{array}$ & $\begin{array}{r}36 \\
8 \\
5 \\
2\end{array}$ \\
\hline & Incorrect & $\begin{array}{l}\text { Swimming in polluted water } \\
\text { Swimming in dirty water } \\
\text { Not wearing shoes } \\
\text { Lack of hygiene } \\
\text { Others } \\
\text { Total }\end{array}$ & $\begin{array}{r}2 \\
10 \\
4 \\
3 \\
2 \\
52\end{array}$ & $\begin{array}{l}\text { Eating unwashed fruits } \\
\text { Contact with dirt } \\
\text { Drinking polluted water } \\
\text { Not wearing shoes } \\
\text { Others } \\
\text { Total }\end{array}$ & $\begin{array}{r}9 \\
7 \\
5 \\
5 \\
5 \\
82\end{array}$ \\
\hline \multirow[t]{2}{*}{$\mathrm{G} 2$} & Correct & $\begin{array}{l}\text { Bathing in water with snails } \\
\text { Feces in the water } \\
\text { Swimming in any type of water } \\
\text { Others }\end{array}$ & $\begin{array}{r}23 \\
6 \\
5 \\
3\end{array}$ & $\begin{array}{l}\text { Bathing in contaminated water } \\
\text { Snail } \\
\text { Others }\end{array}$ & $\begin{array}{r}19 \\
13 \\
2\end{array}$ \\
\hline & Incorrect & $\begin{array}{l}\text { Rain water } \\
\text { Eating unwashed fruits } \\
\text { Drinking polluted water } \\
\text { Not wearing shoes } \\
\text { Not washing hands } \\
\text { Others } \\
\text { Total }\end{array}$ & $\begin{array}{r}7 \\
6 \\
5 \\
4 \\
4 \\
2 \\
65\end{array}$ & $\begin{array}{l}\text { Eating unwashed fruits } \\
\text { Contact with dirt } \\
\text { Others }\end{array}$ & $\begin{array}{r}12 \\
11 \\
2\end{array}$ \\
\hline \multirow[t]{3}{*}{ G3 } & Correct & $\begin{array}{l}\text { Bathing in any type of water } \\
\text { Snail } \\
\text { Feces in the stream } \\
\text { Drinking unfiltered water } \\
\text { Others }\end{array}$ & $\begin{array}{r}32 \\
29 \\
10 \\
8 \\
6\end{array}$ & $\begin{array}{l}\text { Bathing in contaminated water } \\
\text { Snail } \\
\text { Others }\end{array}$ & $\begin{array}{r}28 \\
5 \\
4\end{array}$ \\
\hline & Incorrect & $\begin{array}{l}\text { Walking without shoes } \\
\text { Garbage in the stream } \\
\text { Rain } \\
\text { Lack of hygiene } \\
\text { Others }\end{array}$ & $\begin{array}{l}7 \\
5 \\
5 \\
4 \\
4\end{array}$ & $\begin{array}{l}\text { Contact with dirt } \\
\text { Eating unwashed fruits } \\
\text { Not wearing shoes } \\
\text { Others }\end{array}$ & $\begin{array}{r}18 \\
13 \\
3 \\
3\end{array}$ \\
\hline & & Total & 110 & Total & 74 \\
\hline
\end{tabular}

$a$ : multiple answers included. 
Results showed that students relate transmission to activities such as swimming and bathing in streams. The incorrect anwers were also related to transmission of other helminthoses such as "not washing hands before eating" and "walking without shoes". It is interesting to note that no one mentioned anything related to sanitation and potable water supply (Table III).

Both correct and incorrect answers related to transmission in all three groups (Table III) are strongly related to the idea that schistosomiasis is transmitted through dirty water and dirty things expressed by such terms as "water with feces", "dirty water", "polluted water", "contact with dirt" and "garbage in the stream" and also in relation to behavior "drinking polluted water", "not washing hands" and "eating fruits without washing" (Table III). Like prevention, most answers related to transmission were related to snails, such as "swimming and bathing in water with snails" or only "snails" (Table III).

\section{DISCUSSION}

This study indicates the potential benefit of a health education program administered to the schoolchildren in Caju, since they showed a low level of knowledge about prevention and transmission of schistosomiasis in the pretest, which could be raised using the educational intervention (Table I). As in other rural communities in northern Minas Gerais, children in Caju know that schistosomiasis is a parasitic disease transmitted by a verme (worm) and that water is involved in transmission of the disease, but most of them associate infection with polluted water and lack of hygiene (Table III). Most answers in both prevention and transmission in the pre-test were related to contact with polluted water and excreta in the stream being the word caramujo (snail) used several times and associated with schistosomiasis. Although most studies have found similar results, showing schistosomiasis as a water-borne disease that is contracted through contact with streams, they fail to describe snails as being part of the life cycle (Uchôa et al. 2000, Gazzinelli et al. 2002, Sow et al. 2003).

This perceived relationship between schistosomiasis and snails before and after the intervention (Tables II, III) could be a result of the education materials from the Ministry of Health and Funasa, which emphasize aquatic snails but fail to fully describe the role of the intermediate host in the life cycle of S. mansoni. Bachelar (1996) points out that students usually remember figures and pictures that are usually more concrete and easy to understand than texts that are more abstract, when explaining phenomena such as the function of snails in the transmission and prevention of schistosomiasis. The use of too many pictures or other omissions or even simplifications of textbook information may thus impede abstract thinking which is essential to fully grasp the complexity of the transmisison cycle and its relevance in the every day lives of students.

The challenge of the health educator is to help students to overcome such initial misconceptions and promote critical thinking about the problems and health implications of schistosomiasis. Although we worked with students trying to show them the $S$. mansoni life cycle, the transmission, and prevention of infection during our intervention program in Groups 1 and 2 we could not fully eliminate various misconceptions, as shown in the post-test answers (Table II, III).

On the other hand, the answers in the pre-tests of both Groups 1 and 2 showed that students already had some information about schistosomiasis which was different from what has been presented in other studies in hypoendemic areas where $S$. mansoni became endemic in recent years. This includes the study by Silva et al. (2002), in an endemic area in the state of São Paulo, which reported that most people did not know anything about schistosomiasis.

Our results clearly show a significant change in knowledge of transmission and prevention of schistosomiasis using the social representation and the experience of illness approach (Table I). Similar results were achieved by studies developed by our group in other endemic areas for schistosomiasis and leishmaniasis in Minas Gerais by using a similar model (Gazzinelli et al. 2002, Reis 2003). The failure to raise knowledge levels in Group 2 (cognitive approach) and Group 3 (control group) parallels the outcomes of other health education interventions in other endemic areas in Brazil and other countries using cognitive models (Uchôa et al 2000, Valla \& Oliveira 2001, Silva et al. 2002, Sow et al. 2003). Those authors pointed out that there is a need to go beyond the informative approach, as the one used in Group 2 and to consider two other aspects: (1) the subjective dimensions in health processes that value their health status and risk perception that are fundamental to behavior change and (2) articulation between knowledge and cultural, social, economic and environmental aspects, such as access to basic health services, sanitation and education (Gastaldo 1997, Schall 1998, Barata et al. 2002, Glanz et al. 2002, Reis 2003, Gazzinelli et al. 2005).

Even though criticisms have been directed at the cognitive model (Gastaldo 1997, Peregrino 2002, Reis 2003, Gazzinelli et al. 2005), we decided to apply it in one of our groups because it is still being used in several health educational programs in Brazil and other countries that focus merely on information and on a set of guidelines and norms that individuals are encouraged to follow to prevent disease, even though their impact has been minimal (Sow et al. 2003, Ribeiro et al. 2004).

A few experimental studies that used newer approaches, including the one centering on experience with illness (Gazzinelli et al. 2002), the mobilization or community participation model (Cline \& Hewlett 1996), and the social representation model (Reis 2003), are promising. However, there are barriers to the use of those models in health education programs, such as lack of the necessary skills among professionals, the difficulty of evaluating results, and other constraints (Lima-Costa et al. 2002).

In this study we showed that when the educational process takes into account the previous experiences and knowledge of students and relating them to their place of residence and day-to-day activities, and also the perception of environmental risks relating all this to scientific knowledge it is possible to re-construct their preexistenting knowledge that is necessary to facilitate new 
behaviors related to the control of schistosomiasis. The social representation and experience model is congruent with Bachelard's (1996) conceptual framework. His work was based on the idea that the individuals' primary experience and common sense are obstacles to shared and dynamic knowledge. Thus, according to Bachelard (1996), health-related knowledge of individuals that is basically influenced by their socioeconomic status and fragments of scientific knowledge must be the starting point of health education actions in planning viable educational interventions that can overcome knwledge barriers.

An example for this approach is found in the pre-test results in Group 1, which identified dirty water and water that contained excreta and garbage as possible source of infection (Table II). To change this misinformation, the researchers filled containers with visibly clean stream water containing cercarie and containeers with dirty water from another stream to show the students. After looking at the two samples of water under the microscope they were surprised to see that only the visibly clean water contained cercariae. This demonstration helped students to change their original knowledge of dirty water as the source of schistosome cercariae. Thus students were able to expand their knowledge of the role of polluted and contaminated water as well as clean water in S. mansoni transmission.

Answers from all three groups showed that schistosomiasis is considered a health problem by the children in Caju community but their information comes from popular knowledge that involves three main aspects: water, dirt, and snails (Tables II, III). According to Peregrino (2000), school may play a role in the way students think about health as a set of norms and regulations related to cleanliness and the way they think about disease in relation to dirt. School textbook knowledge, centered on hygiene as the major means of preventing parasitic diseases, may have contributed to the students' responses around prevention and transmission of schistosomiasis, including their emphasis on pollution, dirt, and garbage. The concepts learned in school probably reflect the knowledge of the whole community. This points out the need to review the concepts, ideas, and knowledge that children and adolescents are learning in school. Several studies show that the concept of school space is of the utmost importance for building healthy communities and also for the control of several diseases such as schistosomiasis (Schall et al. 1988, Cyrino \& Pereira 1999, Buss 1999, MacDonald \& Green 2001). This conceptual model may thus facilitate understanding education and health as a permanent integration process.

The better performance of Group 1 seems to be grounded in the idea that health education needs to be a dialogic process between the pre-existent knowledge and scientific knowledge that includes the identification and analysis of contradictory points, confrontation between the two types of knowledge, and the evaluation of the effect produced by the interaction of the two types of knowledge.

School children from all three groups showed a better performance in the prevention than the transmission of schistosomiasis categories (Table I). This may be due to the fact that the concept of prevention follows more closely a normative ground, since it is present both in school and health programs (Gastaldo 1997, Peregrino 2000). Furthermore, biological knowledge, particularly the life cycle of Schistosoma, which usually focuses on transmission, is a complex concept for students that needs a more intense and broader approach to be understood by elementary school students. Even though some elements of the Schistosmoma transmission cycle, such as "snail", "feces", and "water" related to schistosomiasis were described by the students, they were not able to show the connection with the life cycle in all three groups (Tables II, III). These ideas and images have been reported by other studies as commonly known to students but they do not reveal whether students correctly understood the life cycle of Schistosoma (Gazzinelli 2002, Lansdow et al. 2002). Therefore, knowledge about schistosomiasis transmission and the parasite's life cycle should be worked out in detail in all their complexities, taking into consideration the socioeconomic status and cultural experiences of the children.

Also relevant is the fact that students failed to provide in the post-test adequate and concrete information about the role of sanitation and excreta, lack of access to potable water, as well as social and environmental improvements and access to better health services in the prevention of schistosomiasis (Tables II, III). This deficiency reveals the need to priorize mobilization and community participation in health education programs to improve the environment and quality of life of people from those communities (Dias et al. 2000).

The incorrect answers from schoolchildren also reflected an understanding of the general concept of transmission of other helminths (Table III). The responses "walking without shoes" and "eating fruits without washing", indicate preventive actions used by the children and were separate from the main focus which is having contact with water potentially infected with human excreta. These misconceptions emphasize the need to present parasite-specific information in health education interventions. This will help students to associate the correct types of risk behavior with schistosomiasis transmission.

In conclusion, our results indicate that health education programs for the control of schistosomiasis need to focus on the experience and social representation of individuals that can help to identify existing perceptions in communities for the purpose of modifying them with scientific knowledge. However, although knowledge levels surrounding transmission and prevention of schistosomiasis may thus be increased, additional research is necessary to (a) examine the retention of this knowledge over time and (b) whether and to what extent this knowledge is being used effectively by individuals in reducing risk behavior. Health education by itself cannot guarantee the control of schistosomiasis but is a fundamental starting point around which other measures can be built to create a favorable environment for the promotion of higher levels of health consciousness and more critical thinking towards improving the quality of life of communities. 


\section{ACKNOWLEDGMENTS}

To Andrea Casagrande Azevedo, Luciana Alves Silveira Monteiro, and Patrícia Oliveira for assistance with the organization of the educational material and data set and the people of Caju for their cooperation.

\section{REFERENCES}

Abrantes P 1994. Epistemiologia e Cognição, Universidade de Brasília, Brasília, 226 pp.

Asaolu SO, Ofoezie IE 2003. The role of education and sanitation in the control of helminth infections. Acta Trop 86: 283-294.

Bachelard G 1996. A Formação do Espírito Científico: Contribuição para uma Psicanálise do Conhecimento, Contraponto, Rio de Janeiro, p. 29-188.

Barata RB, Briceño-León R 2000. Doenças Endêmicas: Abordagens Sociais, Culturais e Comportamentais, Fiocruz, Rio de Janeiro, p. 233-250.

Barbosa FS 1995. Determination and control of schistosomiasis. Mem Inst Oswaldo Cruz 90: 155-159.

Barbosa FS 1998. Epidemiology and anthropology: an integrated approach dealing with bio-socio-cultural aspects as strategy for the control of endemic diseases. Mem Inst Oswaldo Cruz 93: 59-62.

Buss PM 1999. Promoção e Educação em Saúde no âmbito da Escola Nacional de Saúde Pública. Cad Saúde Públ 15: 177-185.

Cardoso MHCA, Gomes R 2000. Representações sociais e história; referências teórico-metodológicos para o campo da saúde coletiva. Cad Saúde Públ 16: 499-506.

Cline BL, Hewlett BS 1996. Community-based approach to schistosomiasis control. Acta Trop 61: 107-119.

Coura JR 1995. Control of schistosomiasis in Brazil: perspectives and proposals. Mem Inst Oswaldo Cruz 90: 257-260.

Coura-Filho P 1998. Participação popular no controle da esquistossomose através do Sistema Único de Saúde (SUS), em Taquaraçu de Minas Gerais (Minas Gerais, Brasil) entre 1985-1995: construção de um modelo alternativo. Cad Saúde Públ 14 (Supl.2): 111-122.

Cross RM 2005. Exploring attitudes: the case for Q methodology. Health Educ Res 20: 206-213.

Cyrino EG, Pereira MLT 1999. Reflexões sobre uma proposta de integração saúde-escola: o projeto saúde e educação de Bocatu, São Paulo. Cad Saúde Públ 15: 39-44.

Dean AG, Dean JS, Colombier D, Brendel KA, Smith DC 1994. EpiInfo. Versão 6: A Word Processing. Database and Statistics for Epidemiology on Microcomputers. Atlanta, USA: Centers for Disease Control and Prevention.

Dewey J 1971. Experiência e Educação, Nacional, São Paulo $101 \mathrm{pp}$.

Dias JCP 2000. Participação, descentralização e controle de endemias no Brasil. In RB Barata, R Briceño-León (org), Doenças Endêmicas: Abordagens Sociais, Culturais e Comportamentais, Fiocruz, Rio de Janeiro, p. 269-299.

Dias LC, Marçal Jr O, Glasser C 1995. Control of schistosomiasis transmission. Mem Inst Oswaldo Cruz 90: 285-288.

Dorfman L, Wallack L, Woodruff K 2005. More than a mes- sage: framing public health advocacy to change corporate practices. Health Educ Behav 32: 320-336.

Freudenberg N 2005. Public health advocacy to change corporate practices and research. Health Educ Behav 32: 298319.

Funasa-Fundação Nacional de Saúde 2002. Guia de Vigilância Epidemiológica, vol. 1, 5a. ed., Brasília, p. 275-286.

Gastaldo D 1997. "É a educação em saúde saudável?”. Educação Realidade 22: 47-168.

Gazzinelli A, Gazzinelli MF, Cadete MM, Pena Filho S, Sá RI, Kloos H 1998. Sociocultural aspects of schistosomiasis mansoni in an endemic area in Minas Gerais, Brazil. Cad Saúde Públ 14: 841-849.

Gazzinelli MF, Gazzinelli A, Santos RV, Gonçalves LAO 2002. A interdição da doença: uma construção cultural da esquistossomose em área endêmica de Minas Gerais, Brasil. Cad Saúde Públ 18: 1629-1638.

Gazzinelli MF, Gazzinelli A, Reis DC, Penna CMM 2005. Educação em saúde: conhecimentos, representações sociais e experiências da doença. Cad Saúde Públ 21: 200-206.

Glanz K, Lewis FM, Rimer BK 2002. Health Behavior and Health Education: Theory, Research and Practice. 3rd ed., Jossey-Bass, San Francisco, 496 pp.

Guang-Han H, Jia H, Kuang-Yu S, Dan-Dan L, Zhang J, ChunLi C, Jing X, Dong L, We-Seng J 2005. The role of health education and health promotion in the control of schistosomiasis: experiences from a 12-year intervention study in the Poyang Lake area. Acta Trop 96: 232-241.

Kloos H 1995. Human behavior, health education and schistosomiasis control: a review. Soc Sci Med 40: 1497-1511.

Kloos H, Gazzinelli A, Van Zuyle P 1998. Microgeographic patterns of schistosomiasis: examples from Africa and Brazil. Mem Inst Oswaldo Cruz 93: 37-50.

Lansdown R, Ledward A, Hall A, Issae W, Yona E, Matulu J, Mweta M, Kihamia C, Nyandidi U, Bundy D 2002. Schistomiasis, helminth infection and health education in Tanzania: achieving behaviour change in primary schools. Health Educ Res 17: 425-433.

Levy SN, Silva JJC, Cardoso IRF, Werberich PM, Moreira LLS, Montiani H, Carneiro RM 2003. Educação em Saúde: Histórico, Conceitos e Propostas, Ministério da Saúde, Brasília, $21 \mathrm{pp}$.

Lima e Costa MF, Guerra LH, Firmo JOA, Pimenta F Jr, Uchôa E 2002. Um estudo epidemiológico da efetividade de um programa educativo para o controle da esquistossomose em Minas Gerais. Rev Bras Epidemiol 15: 116-128.

MacDonald MA, Green LW 2001. Reconciling concept and context: the dilemma of implementation in school-based health promotion. Health Educ Behav 28: 749-768.

Mohr A, Schall VT 1992. Rumos da educação em saúde no Brasil e sua relação com a educação ambiental. Cad Saúde Públ 8: 199-203.

Moscovici S 2003. Representações Sociais: Investigações em Psicologia Social, Vozes, Rio de Janeiro, 404 pp.

Parker EA, Bladwin GT, Israel B, Salinas MA 2004. Application of health promotion theories and models for environmental health. Health Educ Behav 31: 491-504. 
Peregrino M 2000. Uma questão de saúde: saber escolar e saber popular nas entranhas da escola. In VV Valla, Educação e Saúde, DP\&A, Rio de Janeiro, p. 7-32.

Poggensee G, Krantz I, Nordin P, Mtweve PS, Ahlberg B, Mosha G, Freudenthal S 2005. A six-year follow-up of schoolchildren for urinary and intestinal schistosomiasis and soil-transmitted helminthiasis in northern Tanzania. Acta Trop 93: 131-140.

Reis DC 2003. Educação em Saúde Baseada nas Representações Sociais da Leishmaniose Tegumentar, Universidade Federal de Minas Gerais, Belo Horizonte, 297 pp.

Ribeiro PJ, Aguiar LAK, Toledo CF, Barros SMO, Borges DR 2004. Educational program in schistosomiasis: a model for a methodological approach. Rev Saúde Públ 38: 1-6.

Schall VT 1998. An interactive perspective of health education for tropical disease control: the schistosomiasis case. Mem Inst Oswaldo Cruz 93: 51-58.

Sow S, Vlas JS, Mbaye A, Polman K, Gryseels B 2003. Low awareness of intestinal schistosomiasis in Northern Senegal after 7 years of health education as part of intense control and research activities. Trop Med Hyg 8: 744-749.

Uchôa E, Barreto MS, Firmo JOA, Guerra HL, Pimenta Jr FG, Lima e Costa MFF 2000. The control of schistosomiasis in Brazil: and ethno-epidemiological study of the effectiveness of a community mobilization program for health education. Soc Sci Med 51: 1529-1541.

Valla VV, Oliveira RM 2001. As condições e as experiências de vida de grupos populares no Rio de Janeiro: repensando a mobilização popular no controle do dengue. Cad Saúde Públ 17: 77-88.

Vascocelos EM 1998. Educação popular como instrumento de reorientação das estratégias de controle das doenças infecciosas e parasitárias. Cad Saúde Públ 14: 39-57.

WHO-World Health Organization 2001. Report of the WHO Informal Consultation on Schistosomiasis in Low Transmission Areas: Control Strategies and Criteria for Elimination, London, p. 13-20.

Ximenes RAA, Southgate B, Smith PG 2000. Migration and urban schistosomiasis. The case of São Lourenço da Mata, Northeast of Brazil. Rev Inst Med Trop São Paulo 42: 209-217. 
